\title{
MARCIN IWANICKI
}

\section{RELIGIA PRZEZ CZARNY MONOKL}

Książka Religia jako idolatria. Esej filozoficzny o nieuchronności elementów idolatrycznych $w$ religii (= ZIEMIŃSKI 2020) w sześciu rozdziałach omawia różne aspekty zjawiska idolatrii: jej formy, sposoby zwalczania, domniemaną nieuchronność, źródła i znaczenie. Wszystkie rozważania są osnute wokół głównej tezy, zgodnie z którą religia jest z istoty czy z konieczności idolatrią. Idolatria jest w tym kontekście rozumiana jako „oddawanie czci przedmiotom skończonym błędnie utożsamianym z Bogiem" (ibid., 217). Łączy się więc z błędem, polegającym na utożsamieniu czegoś skończonego - na przykład rytuału, obiektu, instytucji czy pojęcia - z samym Bogiem. Modelowym przykładem owego błędu omawianym w książce jest Eucharystia, w której „Bóg zostaje sprowadzony do konkretnych fragmentów materii” (ibid., 155). Poniższy komentarz składa się z dwóch części: uwag uściślających główne tezy książki oraz uwag polemicznych.

\section{UWAGI UŚCIŚLAJĄCE}

1. Z przyjętego określenia idolatrii wynika, jak się wydaje, że jeśli osoba religijna ma świadomość różnicy między Bogiem a przedmiotami skończonymi, nie mamy do czynienia z idolatrią. W związku z tym obrona głównej tezy książki wymaga uzasadnienia tezy pomocniczej, zgodnie z którą człowiek religijny ma naturalną i nieodpartą skłonność do pomijania tej różnicy — wskutek nieświadomości, braku skupienia, zapomnienia itp., a być może nawet świadomie, by nadać swojemu życiu sens i zyskać nadzieję

Dr Marcin Iwanicki - Katolicki Uniwersytet Lubelski Jana Pawła II, Wydział Filozofii, Instytut Filozofii, Katedra Historii Filozofii Nowożytnej i Współczesnej; adres do korespondencji: Al. Racławickie 14, 20-950 Lublin; e-mail: miwanick@gmail.com; ORCID: https://orcid.org/00000002-3904-0291. 
na zbawienie. Inaczej mówiąc, należy pokazać, że wpisane w naturę człowieka religijnego pragnienie poznania Boga prowadzi nieuchronnie do utożsamienia Go z przedmiotami skończonymi; że zachowanie odpowiedniego „dystansu” wobec skończonych przedmiotów, z których korzysta się w religii, jest niemożliwe ${ }^{1}$. Autor zdaje się wprost przyjmować tę tezę pomocniczą, na przykład gdy pisze, że każdy, „kto uważa, że Bóg jest różny od ludzkich o Nim wyobrażeń, przyznaje zarazem, że czci raczej te wyobrażenia niż samego Boga” (ZIEMIŃsKi 2020,153) oraz że „człowiek jest istotą symboliczną, niezdolną do życia bez jakichkolwiek idoli" (ibid., 147). Książka jednak nie zawiera obrony tej kluczowej tezy. Brak takiej obrony jest częściowo zrozumiały, nie jest bowiem jasne, jak autor miałby ją uzasadnić, nawet jako tezę empiryczną dotyczącą znanych mu osób religijnych, nie wspominając o mocniejszej tezie dotyczącej wszystkich możliwych ludzi religijnych.

Teza pomocnicza wymaga uzasadnienia, ponieważ w typowych przypadkach komunikacji za pośrednictwem przedmiotów skończonych taka błędna zamiana właściwego adresata na obiekt pośredniczący nie jest czymś naturalnym i nieuniknionym - na przykład w czasie rozmowy telefonicznej nikt nie myli rozmówcy $\mathrm{z}$ telefonem. Muszą więc istnieć jakieś szczególne cechy komunikacji z Bogiem wyjaśniające nieuchronność zjawiska przeniesienia w tym konkretnym przypadku. O ile zdolności poznawcze ludzi są ograniczone, o tyle zdolności Boga są, jak przyjmuje sam autor, nieskończone, jest On więc zapewne w stanie odbierać od ludzi komunikaty, w tym objawy czci przekazywane za pośrednictwem przedmiotów skończonych. Z kolei ludzka skończoność nie wyklucza pośredniego i niedoskonałego poznania Boga, zachowującego świadomość różnicy między Bogiem a przedmiotami skończonymi. Teza książki wydaje się więc fałszywa. Jej gruntowną ocenę utrudnia dodatkowo brak w książce wyraźnego rozróżnienia między niepoznawalnością a poznawalnością pośrednią i niedoskonałą, a także brak omówienia różnych form poznania pośredniego i typów pośredników (poznanie częściowe, poznanie przez skutki, poznanie przez reprezentacje, które są w jakimś aspekcie podobne do reprezentowanego przedmiotu lub tylko umowne, pośredniki przezroczyste i nieprzezroczyste itd.). Analizy przeprowadzone w książce wiele by zyskały, gdyby autor wziął pod uwagę filozoficzne teorie reprezentacji i odniesienia, a także przedstawił różne nasuwające się w tym kontekście analogie, takie jak

\footnotetext{
${ }^{1}$ Wzorem autora będę używać w odniesieniu do Boga zaimków męskich.
} 
możliwość komunikacji między twórcami świadomych i inteligentnych programów komputerowych a stworzonymi przez nich istotami czy możliwość poznania innych niż Bóg bytów nieskończonych i niematerialnych ${ }^{2}$.

2. Teza główna książki wymaga nie tylko obrony, ale również doprecyzowania, ponieważ autor podaje różne, nie zawsze równoważne, jej sformułowania. Najczęściej jest ona formułowana następująco: „religia musi być formą idolatrii albo przestać istnieć". Inaczej mówiąc, autentyczna religia jest niemożliwa; religia jest z istoty czy z konieczności idolatrią. Jak czytamy: „religię można uznać za przedsięwzięcie niemożliwe. $Z$ jednej bowiem strony jej celem jest oddanie należnej czci temu, co absolutnie święte i nieskończone, z drugiej - cel ten można realizować wyłącznie dzięki posłużeniu się skończonymi i materialnymi obiektami, należącymi do sfery profanum" (ibid., 188). Niekiedy jednak spotykamy też następujące sformułowanie: nie sposób uniknąć procesu przekształcania się religii autentycznej, czyli religii opartej na doświadczeniu źródłowym, w idolatrię (ibid., 10). To drugie sformułowanie jest mylące, ponieważ zgodnie z logiką wywodów autora „doświadczenie źródłowe” i „autentyczna religia” są niemożliwe, niemożliwy jest więc również proces przekształcania się „religii autentycznej” $\mathrm{w}$ idolatrię. Zawsze $\mathrm{i}$ wszędzie mamy do czynienia jedynie $\mathrm{z}$ idolatrią. $\mathrm{Z}$ tego samego względu nie jest jasne, dlaczego autor twierdzi niekiedy, że religia umożliwia „przynajmniej minimalną więź” z Bogiem (ibid., 186) oraz że jest ona czymś „uprawnionym, a nawet niezbędnym”, co „pozwala nawiązywać kontakt z bóstwem i oddawać mu cześć” (ibid., 189).

Pojawiające się w książce sformułowania głównej tezy mają ponadto niejednorodny status modalny. Oprócz sformułowania, zgodnie z którym religia $\mathrm{z}$ istoty jest idolatrią, spotykamy też łagodniejsze sformułowanie, zgodnie z którym religia $\mathrm{z}$ istoty stoi przed niebezpieczeństwem przekształcenia się w idolatrię lub że ma skłonność do takiego przekształcenia. Nie ulega jednak wątpliwości, że ambicją autora jest obrona tezy mocniejszej, którą podawane w książce przykłady historyczne mają potwierdzać. Jednoznacznym wyrazem tej mocniejszej tezy są między innymi następujące słowa: „idolatria jest istotną i konieczną cechą religii, nie zaś jedynie cechą przygodną, związaną z jej niektórymi postaciami czy etapami jej historycznego rozwoju" (ibid., 147).

\footnotetext{
${ }^{2} \mathrm{Na}$ przykład w myśl wpływowej koncepcji nazw własnych skuteczne odniesienie takich nazw nie zależy od związanych z nimi deskrypcji. Zob. Alston 1989, 103-117. Uwzględnienie dyskusji dotyczących statusu wyrażenia „Bóg” oraz różnych teorii odniesienia wydaje mi się niezbędne w filozoficznym omówieniu idolatrii.
} 
3. Z tezą główną łączy się w książce niejednoznaczna ocena wartości religii. Autor deklaruje wprawdzie, że jego celem ,nie jest ani obrona, ani krytyka jakiegokolwiek z istniejących kultów, lecz opis niezbędnych warunków funkcjonowania religii" (ZIEMIŃSKI 2020, 11) oraz że mimo idolatrycznego charakteru religia może być pod pewnymi warunkami czymś wartościowym, istnieją jednak silne przesłanki, aby z jego analiz wyciągnąć wniosek przeciwny. Z jednej strony czytamy: „nie każda postać idolatrii musi być złem, jeśli bowiem ludzie szczerze czczą Boga za pośrednictwem określonych przedmiotów materialnych, to nie należy ich za to ganić. Złem byłoby jedynie takie sprawowanie kultu, o którym wyznawcy określonej religii z całą pewnością wiedzieliby, że Bóg go nie akceptuje, a mimo to nadal by przy nich trwali" (ibid., 184-185). W tym cytacie mamy pewien warunek niedopuszczalności idolatrii, mianowicie pewność, że dana jej forma jest nieakceptowalna dla Boga. Biorąc pod uwagę, że w świetle wywodów autora taka pewność jest z zasady wykluczona, ponieważ życie wewnętrzne Boga jest nam całkowicie niedostępne, żadna idolatria nie mogłaby zostać uznana za niedopuszczalną. Oprócz tego warunku pojawia się w książce bardziej informatywne kryterium moralne: religia jest mniej lub bardziej zła, zależnie od tego, w jakim stopniu jej elementy idolatryczne są fałszywe i gorszące (ibid., 183), a ludzie religijni mają prawo do wolności wyznania i praktyk religijnych, jeśli nikogo nie krzywdzą. $Z$ tego kryterium wynika, że dobra byłaby taka religia, która nie zawiera żadnych elementów fałszywych i gorszących. To jednak jest niemożliwe, ponieważ religia jest $\mathrm{z}$ istoty idolatrią, a idolatria z definicji opiera się na fałszywym przekonaniu. Komuś, kto ceni prawdę o świecie i przyjmuje pozostałe założenia autora, trudno uniknąć wniosku, że lepiej by było, gdyby religia nie istniała, ponieważ jest ona $\mathrm{z}$ istoty fałszem — i to fałszem dotyczącym spraw najważniejszych egzystencjalnie. Również z wewnątrzreligijnego punktu widzenia idolatria wydaje się czymś jednoznacznie negatywnym, „fałszywym kultem”, „grzechem najcięższym, a zarazem najbardziej podstawowym, stanowiącym źródło wszelkiego innego zła" (ibid., 122).

\section{UWAGI POLEMICZNE}

Omawiana książka w wielu punktach skłania do dyskusji. W swoim komentarzu ograniczę się do jej warstwy filozoficznej, pomijając te części książki, które ściśle biorąc należą do historii intelektualnej lub teologii. 
Podobnie jak autor będę mówić ogólnie o „religii”, choć obu nas interesuje przede wszystkim chrześcijaństwo. Zanim przejdę do uwag krytycznych, chciałbym wspomnieć o jednym wątku książki, z którym w zasadzie się zgadzam. Jest to wątek poboczny i nieistotny z punktu widzenia głównej tezy książki, nie jest on również oryginalny, ale zajmuje w książce sporo miejsca (rozdziały 2.6 i 4.3). Otóż podobnie jak autor dostrzegam wśród wielu przedstawicieli chrześcijaństwa brak otwartości i życzliwości wobec różnych form inności, widoczny m.in. w stosunku do niewierzących, przedstawicieli innych religii i kultur, a także osób nieheteronormatywnych ${ }^{3}$. Poza tym równie krytycznie jak autor oceniam nadmierne uprzywilejowanie społeczne i hierarchiczność Kościoła, prowadzące do triumfalizmu i megalomanii jego wysokich dostojników oraz do konformizmu i karierowiczostwa niższego duchowieństwa. Nie mam też wątpliwości, że do myślenia chrześcijan wkradają się nieraz poważne błędy. Nie jest tajemnicą, że luminarze tej religii bronili w przeszłości niewolnictwa, prześladowań i karania śmiercią heretyków, a niektórym teologom i filozofom do dziś wydaje się, że Summa teologii jest sumą wszystkich mądrości. Problemy te nie dotyczą jednak, według mnie, właściwie rozumianej istoty chrześcijaństwa, lecz jego określonych i historycznie zmiennych form, a część z nich trapi również instytucje świeckie. Są to rzeczy znane i wielokrotnie analizowane, wspominam o nich jedynie po to, aby odsunąć je na bok. Ich znaczenia nie można właściwie oszacować, wykreślając z rejestru pozytywne strony tej religii, jak to czyni autor, który patrzy na nią wyłącznie przez tytułowy czarny monokl. Charakterystyczną cechą książki jest przy tym pomijanie pozytywnych, liberalnych i heterodoksyjnych wariantów religii. Autor chętnie kataloguje przykłady rozmaitych błędnych poglądów i praktyk religijnych, będących wyrazem ludzkiej słabości i niegodziwości oraz nadużywania władzy i autorytetu $\mathrm{w}$ ramach religii. Takie przykłady nie mogą jednak udźwignąć ciężaru argumentu na rzecz forsowanej przez niego tezy, zwłaszcza jeśli dopuszczamy możliwość stopniowego oczyszczania religii z rozmaitych przejawów zła moralnego i z błędów intelektualnych. Tryby historii kręcą się powoli, ale nie stoją w miejscu.

Po tym zastrzeżeniu przechodzę do części polemicznej. W kolejnych akapitach chciałbym wskazać cztery wątki do dalszej dyskusji.

\footnotetext{
${ }^{3} \mathrm{Na}$ temat stosunku do osób nieheteronormatywnych zob. AdAms 2020, 5-18; NussBaum 2004. Warto też sięgnąć po książkę Renaty Ziemińskiej Niebinarne i wielowarstwowe pojęcie $p t c i(=$ ZIEMIŃSKA 2018).
} 
1. Pierwszy z nich dotyczy rozumienia idolatrii jako „oddawania czci przedmiotom skończonym błędnie utożsamianym z Bogiem”. To określenie jest, jak sądzę, za wąskie i wymaga doprecyzowania. Oddawanie czci nie jest jedyną postawą, w jakiej wyraża się idolatria. Może ona również przybrać postać nadmiernej miłości, nadziei na szczęście własne, a nawet — jak zauważa w innym miejscu sam autor - przedstawień umysłowych i językowych, takich jak idea Boga i nazwa „Bóg”. Ponadto niewłaściwym przedmiotem czci nie muszą być przedmioty fizyczne czy zmysłowe ani nawet skończone. Mogą nim być również takie przedmioty, jak nieskończony świat przyrody, nieskończone ciągi liczb czy transcendentne wartości prawdy, dobra i piękna. Ograniczenie idoli do przedmiotów fizycznych wydaje się niepotrzebne również z tego względu, że z góry wyklucza prawdziwość idealizmu metafizycznego czy immaterializmu, a także możliwość idolatrii wśród istot czysto duchowych, takich jak aniołowie czy platońskie dusze. Można sobie wyobrazić, że takie istoty dopuszczają się idolatrii, przedkładając nad Boga jakieś mniejsze dobro, niekoniecznie skonkretyzowane fizycznie ${ }^{4}$.

Do rozważenia pozostaje również konieczność przyjęcia warunku błędnej identyfikacji. Niekiedy sam autor pomija ów warunek (na przykład w ZIEMIŃSKI 2020, 153 nawet osoba świadoma różnicy między Bogiem a przedmiotami skończonymi zostaje potraktowana jako idolatra). Jego chwiejny status ujawnia pewien dylemat, przed którym staje osoba religijna przyjmująca tezę o idolatryczności religii. Ilustracją tego dylematu jest przywołany przez autora spór dwóch filozofów nowożytnych: „Pierre Bayle zastanawiał się, czy lepiej jest w ogóle nie wierzyć w Boga (pozostając ateistą), czy mieć o nim błędne pojęcia (i popaść w idolatrię). W odpowiedzi przychylił się do tezy Plutarcha, że lepszy jest brak jakiejkolwiek opinii niż opinia fałszywa. Voltaire uważał jednak takie rozwiązanie za błędne; z punktu widzenia ludzi

\footnotetext{
${ }^{4}$ Sprawę adekwatnego określenia idolatrii komplikuje dodanie w jednym miejscu następującego członu: „lub posłużenie się rzeczami świętymi w celach niereligijnych (świeckich), zwłaszcza dla realizacji interesów doczesnych” (ZIEMIŃSKI 2020, 13-14) czy, jeszcze szerzej, ,poczucie własnej świętości oraz instrumentalizacja obiektu czci" (ibid., 168; podkreślenie M. I.). Autor nie omawia nigdzie relacji między tymi dwoma sensami idolatrii. Wychodząc od drugiego z nich, można wskazać inną genezę idolatrii, mianowicie pragnienie uzyskania kontroli nad Bogiem lub innymi ludźmi. Kierowani tym pragnieniem, świadomie lub nie, ludzie redukowaliby Boga do jego substytutu materialnego, nad którym mogą mieć władzę, a następnie wykorzystywaliby ów substytut do realizacji własnych dążeń. W tej interpretacji podmiotowym źródłem idolatrii byłoby nie tyle pragnienie oddawania Bogu czci, ile pragnienie kontroli, a religia byłaby czymś od początku sfabrykowanym przez ludzi. Za interpretacją uwypuklającą pragnienie kontroli przemawiają uwagi autora o funkcjonalizacji Boga i Chrystusa przez Kościół, dążący wyłącznie do realizacji własnych celów doczesnych. W sprawie dalszej analizy idolatrii zob. HaLberTal i Margalit 1998.
} 
wierzących bowiem, którzy poszukują nadziei, lepiej jest wyznawać bóstwa fałszywe niż żadne (...). Spór ten trudno rozstrzygnąć. Z punktu widzenia pragnienia poznania prawdy rację ma zapewne Bayle (lepiej nic nie wiedzieć, niż fałsz uznawać za prawdę), jednak z punktu widzenia potrzeb egzystencjalnych człowieka, polegających na potrzebie nadziei na zbawienie, rację może mieć Voltaire (lepiej wyznawać religię fałszywą, która pozwala przetrwać trudy życia, niż popaść w rozpacz)" (ZIEMIŃSKI 2020, 22-23). Zderzają się tu więc ze sobą względy teoretyczne i praktyczne: pragnienie prawdy z pragnieniem sensu życia i nadzieją na zbawienie.

Jeśli Voltaire ma rację, to osoba religijna znajduje się w kłopotliwym położeniu. Zakładając prawdziwość wymogu błędnej identyfikacji, wykluczającego świadome przyjmowanie błędnej postawy wobec Boga, osoba religijna jest zmuszona oszukiwać samą siebie. Ma ona pewne racje praktyczne lub motywy psychiczne, aby uczestniczyć w idolatrii, mimo iż przeciwko takiemu uczestnictwu przemawiają racje teoretyczne wskazujące, że idolatria jest fałszywym kultem. W konsekwencji osoba ta podtrzymuje lub wytwarza w sobie przekonanie, że religia nie jest idolatrią, mimo iż ogół posiadanych przez nią danych to przekonanie podważa ${ }^{5}$. Oprócz samooszustwa można rozważyć jeszcze inne możliwości. Być może na przykład osoba religijna jest w pełni świadoma błędu idolatrii i znajduje się w sytuacji podobnej do osoby, która ulega złudzeniu na poziomie zmysłowym, wiedząc jednocześnie na poziomie intelektualnym, iż jest to tylko złudzenie, lub w sytuacji kogoś, kto akceptuje paradoksalne zdanie ,p, ale nie uznaje, że $p$ ”, a dokładniej zdanie o postaci: „To tylko idol, który nie może nadać sensu mojemu życiu i dać mi nadziei na zbawienie, ale nie uznaję, że to tylko idol, który nie może nadać sensu mojemu życiu i dać mi nadziei na zbawienie”.

Wątpliwości budzi nie tylko przyjęte w książce określenie idolatrii religijnej, ale również jej uniwersalizacja. Jak pisze autor, „potrzeba idola jest w ludzkich dziejach dosyć powszechna i w miarę stała” (ibid., 191), a „idolatria obecna $\mathrm{w}$ religii jest przejawem szerszego zjawiska kulturowego, które polega na zastąpieniu rzeczywistych wartości przez rozmaite idole (osoby, rzeczy czy instytucje). Zjawisko to może sugerować, że człowiek jest istotą potrzebującą idoli i tworzącą je po to, aby ważne dla siebie (chociaż nieuchwytne) wartości móc sobie unaocznić, a nawet uobecnić" (ibid., 192-193). Ta hipoteza jest ogólniejsza od poprzedniej, dotyczy bowiem systemu motywacyjnego wszystkich, nie tylko religijnych, ludzi. Idolatria religijna okazuje się tu tylko jednym z przejawów pewnej uniwersalnej potrzeby ludzkiej.

\footnotetext{
${ }^{5}$ Na temat samooszukiwania zob. PiŁat 2013, rozdz. XI oraz FunKhouser 2019.
} 
Wspomniana potrzeba idoli sprawia, że idolatria jest czymś powszechnym w kulturze. Tym, co łączy różne jej odmiany, jest przeniesienie uwagi z właściwego przedmiotu na jakiś jego substytut, który błędnie traktuje się jako ów przedmiot. Owym właściwym przedmiotem nie musi być Bóg, mogą nim być również wartości, takich jak prawda, dobro i piękno. Każdy z nas jest $\mathrm{w}$ dziedzinach kluczowych dla sensu życia istotą nie tylko omylną, ale skazaną na błądzenie. Idolami zastępujemy bowiem nie tylko Boga, ale również wszystko to, co w życiu najcenniejsze. Platońska alegoria jaskini wymaga więc przepisania na nowo ze zmienionym zakończeniem: nie ma wyjścia z krainy cieni.

Uwzględnienie tego ogólniejszego wymiaru idolatrii pozwala lepiej zrozumieć główną tezę książki, którą możemy teraz sformułować następująco: religia będzie idolatrią lub zostanie zastąpiona przez idolatrię świecką. Tak odczytana staje się ona skrajnie pesymistyczną tezą dotyczącą kondycji ludzkiej. Zgodnie z nią człowiek jest istotą absurdalną. Tak jak Syzyf nieustannie wtacza kamień, a Estragon i Vladimir bez końca czekają na Godota, tak człowiek daremnie kieruje swoje akty poznania i działania w stronę tego, co transcendentne, zawsze trafiając w próżnię. Powinowactwo tych fikcyjnych postaci i rzeczywistych ludzi jest niezwykle bliskie, skoro autor przyjmuje, że poznanie tego, co transcendentne, jest z istoty niemożliwe.

$\mathrm{Na}$ tym nie koniec złych wieści. Omawiana uniwersalizacja terminu ,idolatria" na wszystkie dziedziny kultury sprawia, że traci on swój negatywny wydźwięk i kontrast, stając się terminem co najmniej ambiwalentnym. Problem nie polega na tym, że wszystko nie może być idolatrią, bo taka sytuacja jest pojęciowo możliwa, ale na tym, że pojęcie uniwersalnej idolatrii nie jest przydatnym narzędziem analiz świata ludzkiego: To, co jest problemem dla wszystkich, nie jest problemem dla nikogo, jak mawiał biskup Berkeley.

2. Druga sprawa warta dalszego namysłu to geneza idolatrii. Autor wskazuje przede wszystkim na to, że człowiek i Bóg, o ile On istnieje, przynależą do całkowicie odmiennych sfer rzeczywistości. Z jednej strony mamy skończoność i cielesność człowieka, z drugiej nieskończoność i transcendencję Boga. Ta różnica $\mathrm{w}$ sposobie istnienia stwarza, jak sugeruje autor, nieprzekraczalną lukę epistemiczną i komunikacyjną: to, co skończone, nie może poznać tego, co nieskończone i absolutnie transcendentne, ani nawiązać z nim bezpośredniej komunikacji. Nawet gdyby Bóg postanowił objawić się ludziom, to ze względu na ich ograniczenia poznawcze musiałby przybrać postać skończonego przedmiotu (ZIEMIŃSKi 2020, 177) bądź uczynić poznające go podmioty nieskończonymi, czyli dokonać ich „transformacji onto- 
logicznej”. W pierwszym wypadku Bóg straciłby swoją tożsamość, a w drugim straciłby ją człowiek. Tak czy inaczej luka epistemiczna i komunikacyjna nie zostałaby domknięta. Ta luka w połączeniu $\mathrm{z}$ nieodpartym pragnieniem ludzi religijnych, by nawiązać więź z Bogiem, oraz z idolatrycznym charakterem wszystkich ludzkich przedstawień Boga, odpowiada za istnienie idolatrii.

Załóżmy na chwilę, że Bóg rzeczywiście jest nieskończony i absolutnie transcendentny $\mathrm{w}$ tak mocnym sensie, jakim operuje autor. Wydaje mi się, że żadna $\mathrm{z}$ tych dwóch własności Boga (osobno lub łącznie) nie wyklucza możliwości pośredniego i niedoskonałego poznania Boga. Dla porównania: autor przyjmuje w książce, że prawda, dobro i piękno są wartościami transcendentnymi ontologicznie, nie wyklucza jednak samej możliwości ich poznania (być może nie jest w tym punkcie w pełni konsekwentny). Wątpię również, czy wykluczyłby możliwość wiedzy na temat liczb nieskończonych czy nieskończonego świata przyrody. O ile więc nie zrównamy w sposób arbitralny nieskończoności i absolutnej transcendencji z niepoznawalnością, to nie ma powodu, by przyjąć całkowitą niepoznawalność Boga ${ }^{6}$.

Zanim jednak przyjmiemy założenie o absolutnej transcendencji Boga, powinniśmy je uściślić. Transcendencję Boga można bowiem rozumieć na różne sposoby, z których dwa podstawowe to epistemologiczny i ontologiczny. W pierwszym sensie chodzi o całkowitą niepoznawalność Boga $\mathrm{i}$ jego natury, w drugim - o absolutną różnicę między Bogiem a światem, w szczególności światem ludzkim. Przyjęcie w punkcie wyjścia, że Bóg jest całkowicie niepoznawalny przesądzałoby sprawę na korzyść autora; byłoby również nieuprawnione, nie jest to bowiem teza przyjmowana przez większość religii. Natomiast przyjęcie, że Bóg jest transcendentny w sensie ontologicznym, nie wyklucza Jego poznawalności. Teza o różnicy ontologicznej ma różne wersje i jest wciąż żywo dyskutowana ${ }^{7}$. Nawet ci myśliciele, którzy uważają, że Bóg jest ontologicznie transcendentny i niepoznawalny $\mathrm{w}$ swojej istocie (...quid vero sit [Deus] penitus manet incognitum (Akwinata,

\footnotetext{
${ }^{6}$ Niekiedy autor pisze, że Bóg jest niepoznawalny, a niekiedy, że nawet jeśli jest poznawalny, to tylko za pośrednictwem form ludzkich, takich jak przystosowane do człowieka objawienie. Ciekawe uwagi na temat niepoznawalności Boga można znaleźć w Kenny 2019, 499-510. Kenny nie wyklucza możliwości komunikacji z Bogiem ani autentycznej religii.

${ }^{7}$ Jedni twierdzą, że Bóg jest całkowicie poza bytem; inni, że Bóg jest bytem pozakategorialnym, o którym można orzekać w sposób analogiczny lub jednoznaczny; jeszcze inni, że Bóg jest doskonałym i nieskończonym bytem konkretnym i jednostkowym, o którym można orzekać w sposób jednoznaczny, a nawet definiować Go. Poglądy myślicieli religijnych są bardziej zróżnicowane, niż można by sądzić po lekturze recenzowanej książki.
} 
SCG III, 49, 9)), twierdzą zwykle, że możemy poznać Jego własności relacyjne. Samo przyjęcie, że Bóg jest absolutnie transcendentny $\mathrm{w}$ sensie ontologicznym, nie rozstrzyga więc sprawy, a przyjęcie, że jest również absolutnie transcendentny w sensie epistemologicznym, wymaga obrony, której autor nie podejmuje. Ostatecznie pozostajemy z dwoma pytaniami: Jak jest w książce rozumiana transcendencja? Czy tak rozumianą transcendencję musi przyjmować każda religia, a w szczególności każda wersja chrześcijaństwa?

3. Trzeci temat, na który chciałbym zwrócić uwagę, to ocena wartości i skuteczności idolatrii z punktu widzenia Boga, a nie człowieka religijnego lub niereligijnego. Można się zastanawiać, czy w oczach Boga nieumyślna i nieunikniona idolatria jest czymś lepszym czy gorszym niż jej brak. Ściśle biorąc, w świetle tezy o niepoznawalności Boga pytanie to nie ma odpowiedzi, ale pewne uwagi autora dotyczące moralnej natury Boga wyraźnie sugerują odpowiedź. Wprawdzie określa on religię idolatryczną jako „fałszywy kult" (ZIEMIŃsKi 2020, 13), a niektóre jej formy jako bluźnierstwo, czyli znieważenie Boga, co mogłoby sugerować, że idolatria jest czymś negatywnym, jednocześnie wyraża jednak wątpliwość, ,jak człowiek wierzący w Boga mógłby świadomie i celowo go znieważać” (ibid., 16). Jak pisze: ,jeżeli bowiem istnieje rzeczywiście ontyczna przepaść między skończonym i grzesznym światem a nieskończonym i świętym Bogiem, to trudno zrozumieć możliwość zaistnienia zniewagi, wyrządzonej przez ludzi swojemu Stwórcy. Tym bardziej niepojęta jest zniewaga związana z błędną formą oddawania Mu czci, skoro bowiem jest On absolutnie transcendentny i nieskończony, to człowiek nie może wiedzieć, jakie formy kultu są stosowne” (ibid., 129). I dalej: „,nawet Bóg, aby objawić człowiekowi swoją obecność, musi użyć środków dostosowanych do ludzkiego aparatu poznawczego, okazuje się zatem nie takim, jakim jest w swoim wewnętrznym bycie, lecz takim, jakim człowiek potrafi Go poznać. [...] Skoro jednak działanie to jest motywowane racjami epistemologicznymi, wynikającymi z ludzkiej kondycji poznawczej, to trudno się w nim dopatrywać grzesznej idolatrii” (ibid., 130). Autor odrzuca też jednoznacznie tezę, że idolatrów czeka, z powodu ich błędów, wieczne potępienie, i twierdzi, że taka kara byłaby niezgodna $\mathrm{z}$ naturą Boga (ibid., 138). Wydaje się zresztą, że gdyby Bóg wiedział, iż religia jest z istoty idolatrią, a idolatria nieuchronnie prowadzi do potępienia, to jako istota kochająca zapewne w ogólne nie dopuściłby do powstania religii. W przeciwnym razie postawiłby Bogu ducha winnych ludzi w sytuacji „paragrafu 22” — byliby potępieni zarówno praktykując religię, jak i jej nie praktykując. 
Przywołane uwagi autora nasuwają pewne rozwiązanie problemu idolatrii pominięte $\mathrm{w}$ książce. Zgodnie z tym rozwiązaniem to, co początkowo może się wydawać idolatrią i co spełnia warunki idolatrii wytyczone przez autora, w rzeczywistości idolatrią być nie musi. Otóż Bóg może nawiązać kontakt z ludźmi, dostosowując swoje objawienie do ich zdolności poznawczych oraz oceniając ich niedoskonałe praktyki religijne w świetle ich autentycznego pragnienia nawiązania z Nim kontaktu, a w szczególności oddania Mu czci. Wprawdzie ludzie, wskutek swojej ułomności, niewłaściwie identyfikują przedmiot swojej czci, ale Bóg, właściwie odczytując ich pragnienia i intencje, ich „zmysł boskości, spragniony autentycznego sacrum” (ibid., 169), przyjmuje składane przez nich objawy czci, o ile spełniają one przyjmowane w książce wymogi moralne, takie jak niekrzywdzenie innych istot czujących i niemanipulowanie Bogiem. Ostatecznie więc ludzie religijni pragną oddać cześć Bogu, Bóg zaś, znając ich rzeczywiste intencje, przyjmuje tę cześć. Ich praktyki pozwalają więc skutecznie nawiązać więź z Bogiem, co sugeruje, że nie mamy do czynienia z idolatrią — a w każdym razie nie $\mathrm{z}$ taką idolatrią, która wykluczałaby autentyczną religię.

Jeśli taka możliwość wchodzi w grę, to warunki wytyczone w przyjętym w książce określeniu idolatrii, nawet po zaproponowanych modyfikacjach, są nieadekwatne, pomijają bowiem intencje ludzi religijnych oraz domniemaną postawę Boga wobec religii. Za pewne potwierdzenie tego rozwiązania — niezgodnego z wyraźnymi deklaracjami autora — można potraktować następujące słowa: „Nie ma tymczasem wątpliwości, że nikt nie może z całą pewnością wiedzieć, czy Bóg istnieje, jaki jest i jak należy Go czcić. W takim razie nie wolno również nikomu narzucać określonych zachowań rytualnych jako rzekomo zgodnych z wolą Boga (a tym bardziej jako jedynych dopuszczalnych); jeśli bowiem Bóg istnieje i jest rzeczywiście zatroskany o los ludzi, to przyjmie z ich strony każdą formę adoracji, która nie będzie wyrządzać krzywdy Jego stworzeniom" (ibid., 142)

Przywołuję podane wyżej rozwiązanie, aby pokazać, że główna teza książki jest problematyczna nawet przy uznaniu wszystkich założeń autora. Nie wszystkie wydają mi się jednak zasadne. Na przykład odrzucając tezę o całkowitej niepoznawalności Boga, człowiek religijny ma do dyspozycji inne, bardziej optymistyczne i według mnie lepsze odpowiedzi. Tradycyjna

\footnotetext{
${ }^{8}$ Przedstawione rozwiązanie współgra m.in. $\mathrm{z}$ hipotezą pluralizmu religijnego w wersji Johna Hicka. Zgodnie $\mathrm{z}$ tą hipotezą ostateczna rzeczywistość boska sama w sobie jest niepoznawalna i wykracza poza wszelkie sposoby jej doświadczania i konceptualizacji, ale umożliwia kontakt z nią za pośrednictwem (skrojonych na miarę ludzką) jej empirycznych interpretacji. Zob. Hick 1989, cz. IV.
} 
odpowiedź chrześcijańska mogłaby przybrać następującą postać: „Po upadku pierwszych ludzi utraciliśmy bezpośredni kontakt z Bogiem, a do naszych praktyk zaczęły się wkradać elementy idolatrii. Mamy silną skłonność do przypisywania nadmiernej wartości przedmiotom świata stworzonego, wysuwamy roszczenie do absolutnej prawdziwości naszej religii, a niekiedy próbujemy manipulować Bogiem w celu osiągnięcia własnego szczęścia. Podobne błędy popełniamy nie tylko w indywidualnym życiu duchowym, ale również w obrębie instytucji religijnych. Ułomności te nie są jednak nieuchronne, choć stale należy je mieć w pamięci i mierzyć się z nimi duchowo. Bóg, jak mamy nadzieję, ocenia je wyrozumiale, zdając sobie sprawę z naszej niedoskonałości. Spodziewamy się również, że ułomności te nie są trwałe - w życiu przyszłym zostaną zniesione przez moc Boga, być może nawet w odniesieniu do wszystkich istot stworzonych"9.

4. Autor podkreśla wielokrotnie, że ,wszelkie mówienie o Bogu, jak również każdy sposób pojmowania Boga jest nieuchronnie procesem tworzenia idola" (ZIEMIŃSKI 2020, 151). Ostatni problem, który chciałbym zasygnalizować, jest następujący. Bóg, o którym mówi autor, gdy ocenia różne formy idolatrii, niebezpiecznie przypomina tzw. Boga filozofów, a więc jednego z idoli. W wielu miejscach książki autor przypisuje Bogu dosłownie rozumiane cechy nieskończoności, absolutnej transcendencji, osobowości czy świętości. Stawia to pod znakiem zapytania spójność jego argumentacji. Otóż wniosek o niepoznawalności Boga i niemożliwości dosłownego przypisania $\mathrm{Mu}$ jakichkolwiek własności opiera się na przesłankach, w których przypisuje się Bogu pewne dosłownie rozumiane własności. Autor ginie więc ostatecznie od własnej broni.

Wskazany tu problem można nieco inaczej wyrazić w postaci dylematu, przed jakim staje autor. Przedmiot wyrażenia językowego „istota nieskończona i absolutnie transcendentna" albo jest idolem, albo nim nie jest. Jeśli jest to idol, to nie można się do niego odwołać w argumencie za niepoznawalnością Boga i główną tezą książki. Z kolei jeśli nie jest on idolem, to religia nie musi być idolatrią, ponieważ istnieją nieidolatryczne sposoby poznawczego dotarcia do Boga, takie jak ,istota nieskończona i absolutnie transcendentna".

\footnotetext{
${ }^{9}$ Chrześcijanie mają do dyspozycji różne, mniej lub bardziej optymistyczne, wersje tej tradycyjnej opowieści o upadku i jego konsekwencjach. Znane są również inne odpowiedzi chrześcijańskie, całkowicie rezygnujące z idei upadku pierwszych ludzi, dostosowane do moralnej wrażliwości człowieka współczesnego i danych nauki. Zob. np. Hıck 1966, cz. III i IV oraz HRYNIEWICZ 2015, 177-250.
} 
Być może autor odpowiedziałby, że przypisuje Bogu takie atrybuty jedynie w imieniu osoby religijnej, a nie własnym. Następnie broni tezy warunkowej „jeżeli Bóg posiada takie atrybuty, to wszelka religia jest idolatrią”, dochodząc ostatecznie do wniosku, że religia jest idolatrią. Kłopot w tym, że wiele religii nie przypisuje Bogu absolutnej transcendencji w mocnym sensie ontologicznym, a autor nie wyjaśnia, dlaczego miałyby być zmuszone do jej przyjęcia. Jeśli więc autor przemawia w imieniu osób religijnych czy choćby wszystkich chrześcijan, to błędnie reprezentuje ich stanowisko.

Podsumujmy. Autorowi nie udało się, moim zdaniem, uzasadnić głównej tezy książki i przekonująco wykazać, że idolatria należy do istoty religii, a w szczególności, że należy ona do istoty chrześcijaństwa, którego autor jest wnikliwym i nieustępliwym krytykiem. Przytoczone racje oraz przykłady historyczne skutecznie uzasadniają słabszą tezę, która jest bezsporna, a która głosi, że do religii często wkradają się elementy idolatrii, należy więc zawsze pamiętać o ograniczeniach poznawczych człowieka i ludzkiej omylności, a także pozostawać otwartym na modyfikacje i reinterpretacje reprezentacji i praktyk religijnych. Wspomniane racje nie uzasadniają natomiast tezy mocniejszej, która stanowi o oryginalności książki, a która głosi, że religia jest z konieczności czy z istoty idolatrią. Niewykluczone, że autor nie traktuje tej mocniejszej tezy z zupełną powagą, lecz jedynie jako rodzaj ćwiczenia filozoficznego w duchu sokratejskim, wprawki, której celem jest rzucenie wyzwania umysłom szkolonym $\mathrm{w}$ filozofii. Jeśli tak jest $\mathrm{w}$ istocie, to książkę można uznać za bezapelacyjny sukces.

\section{BIBLIOGRAFIA}

AdAms, Robert Merrihew. 2020. „Ludzka natura, chrześcijańskie powołanie i płcie”. Przeł. Marcin Iwanicki. Analiza i Egzystencja 52: 5-18

Alston, William P. 2019. „Referring to God”. W: IDEM. Divine Nature and Human Language: Essays in Philosophical Theology, 103-117. Ithaca, NY: Cornell University Press.

Funkhouser, Eric. 2019. Self-Deception. London and New York: Routledge.

Halbertal, Moshe, i Avishai Margalit. 1998. Idolatry. Przeł. Naomi Goldlum. Cambridge, MA/ London: Harvard University Press.

HICK, John. 1989. An Interpretation of Religion: Human Responses to the Transcendent. Yale: Yale University Press.

Hick, John. 1966. Evil and the God of Love. New York: Harper \& Row.

HrYNIEWICZ, Wacław. 2015. Wiara rodzi się w dialogu. Kraków: Wydawnictwo WAM.

KenNy, Anthony. 2019. Bóstwo niewysłowione. Przeł. Sylwia Wilczewska. W: Teizm, ateizm i religia. Najnowsze spory $w$ anglosaskiej filozofii analitycznej, red. Piotr Gutowski i Marcin Iwanicki, 499-510. Lublin: Wydawnictwo KUL. 
Nussbaum, Martha. 2004. Hiding from Humanity. Disgust, Shame, and the Law. Princeton: Princeton University Press.

PIŁAT, Robert. 2013. Aporie samowiedzy. Warszawa: Wydawnictwo IFiS PAN.

Quinn, Philip L., i Kevin Meeker (red.). 1999. The Philosophical Challenge of Religious Diversity. Oxford: Oxford University Press.

ZiemińsKa, Renata. 2018. Niebinarne $i$ wielowarstwowe pojęcie ptci. Próba inkluzji danych o osobach interptciowych i niebinarnych, Warszawa: Wydawnictwo Naukowe PWN.

ZiemiŃsKi, Ireneusz. 2020. Religia jako idolatria. Esej filozoficzny o nieuchronności elementów idolatrycznych w religii. Szczecin: Wydawnictwo Uniwersytetu Szczecińskiego.

\section{RELIGIA PRZEZ CZARNY MONOKL}

Streszczenie

Tekst jest polemiką z główną tezą książki Ireneusza Ziemińskiego Religia jako idolatria, która głosi, że religia jest z istoty czy z konieczności idolatrią. Autor argumentuje, że teza ta nie została odpowiednio uzasadniona, a także wskazuje kilka zagadnień poruszonych $\mathrm{w}$ książce, które wymagają dalszego namysłu.

Słowa kluczowe: Bóg; religia; idolatria.

\section{RELIGION THROUGH THE BLACK MONOCL}

\section{Su m mary}

The essay critically examines the main claim of the book Religia jako idolatria [Religion as Idolatry] by Ireneusz Ziemiński, according to which religion is necessarily idolatry. The author argues that the thesis is insufficiently justified and points out several topic that require further discussion.

Keywords: God; religion; idolatry.

Information about the Author: Marcin IwANICKI, PhD - The John Paul II Catholic University of Lublin, Faculty of Philosophy, Institute of Philosophy, Department of the History of Modern and Contemporary Philosophy; correspondence address: Al. Racławickie 14, 20-950 Lublin; e-mail: miwanick@gmail.com; ORCID: https://orcid.org/0000-0002-3904-0291. 